\title{
Do Lemmas Speak German? A Verb Position Effect in German Structural Priming
}

\author{
Franklin Chang, ${ }^{\mathrm{a}}$ Michael Baumann, ${ }^{\mathrm{b}}$ Sandra Pappert, ${ }^{\mathrm{c}}$ Hartmut Fitz ${ }^{\mathrm{d}}$

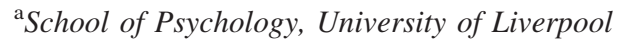 \\ ${ }^{\mathrm{b}}$ Department of Linguistics, University of Leipzig \\ ${ }^{\mathrm{c}}$ LiLi Faculty, Bielefeld University \\ ${ }^{\mathrm{d}}$ Max Planck Institute for Psycholinguistics, Nijmegen
}

Received 21 July 2013; received in revised form 11 April 2014; accepted 14 April 2014

\begin{abstract}
Lexicalized theories of syntax often assume that verb-structure regularities are mediated by lemmas, which abstract over variation in verb tense and aspect. German syntax seems to challenge this assumption, because verb position depends on tense and aspect. To examine how German speakers link these elements, a structural priming study was performed which varied syntactic structure, verb position (encoded by tense and aspect), and verb overlap. Abstract structural priming was found, both within and across verb position, but priming was larger when the verb position was the same between prime and target. Priming was boosted by verb overlap, but there was no interaction with verb position. The results can be explained by a lemma model where tense and aspect are linked to structural choices in German. Since the architecture of this lemma model is not consistent with results from English, a connectionist model was developed which could explain the cross-linguistic variation in the production system. Together, these findings support the view that language learning plays an important role in determining the nature of structural priming in different languages.
\end{abstract}

Keywords: Structural priming; German dative alternation; Sentence production; Lemma; Connectionist neural network; Learning

\section{Introduction}

Verbs are intimately connected with syntactic structures. For example, the verb give can appear in both the double object dative (DO) like the man gave the woman the dress or the prepositional dative (PD) the man gave the dress to the woman. But the semanti-

Correspondence should be sent to Franklin Chang, School of Psychology, University of Liverpool, Bedford Street South, L697ZA Liverpool, UK. E-mail: franklin.chang@liverpool.ac.uk 
cally similar verb donate only appears in the PD the man donated the books to the church and not the DO structure. The tight link between words and syntax has motivated the movement to linguistic theories where syntactic representations are lexicalized (Bresnan, 2001; Pollard \& Sag, 1994).

One phenomenon that supports this lexicalized view of syntax is the lexical boost in structural priming (Pickering \& Branigan, 1998). Structural priming is a tendency for speakers to repeat previously heard syntactic structures (Bock, 1986). In these studies, participants hear a PD prime sentence like $a$ girl sent a ball to her friend, and when they subsequently describe a picture of a dative event, they are more likely to use the same structure in their own description (e.g., the man showed the dress to the woman). Although priming seems to involve abstract syntactic structures (Bock \& Loebell, 1990), the magnitude of priming is boosted when the prime and target share the same verb; this phenomenon is called the lexical boost. The boost has been interpreted as evidence for direct verb-structure links.

Pickering and Branigan (1998) explain priming and the boost in terms of activation in a production network. Prime sentences leave residual activation in structural nodes for PD and DO structures and this creates structural priming. This account assumes that lexical entries called lemmas (Levelt, Roelofs, \& Meyer, 1999), which encode the base form of each verb (e.g., give, gave, giving share the same lemma), are linked with syntactic properties (e.g., transitivity of the verb and tense/aspect). For example, the GIVE lemma has links to both PD and DO structure nodes, but the DONATE lemma only has a link to the PD node. When a prime is processed, residual activation in the link between the verb and its structure node is retained and if the target shares the same verb, then this residual activation in the link creates the lexical boost. The lemma theory predicts that tense and aspect will not influence priming and Pickering and Branigan (1998) found support for this prediction in English (primes with the verb showed primed targets with showed as much as primes with shows and was showing). Thus, in this theory and other lexicalized syntactic accounts (Reitter, Keller, \& Moore, 2011), priming is constrained by the lemma-based architecture of the production system, which separates syntax from tense and aspect.

An alternative account argues that structural priming is due to implicit learning, which is supported by the finding that priming persisted over 10 intervening utterances between prime and target (Bock, Dell, Chang, \& Onishi, 2007; Bock \& Griffin, 2000). Chang, Dell, and Bock (2006) extended this claim by suggesting that priming is due to the same learning mechanism that was used to learn language in the first place. They implemented this idea in a connectionist model which learned an English-like language and used the same learning algorithm to explain abstract structural priming. The model had a dual-pathway architecture that kept syntax and lexical-semantic representations separate (Dual-path model; Chang, 2002). Without this separation, the model would learn lexically specific representations, which would not generalize in a syntactic manner. Thus, the dual-pathway architecture was critical in order to learn syntactic representations that support abstract structural priming.

However, the separation between the pathways kept the model from exhibiting lexical boost effects and Chang et al. (2006, pp. 255-256) hypothesized that the lexical boost 
was due to a separate mechanism. Support for this hypothesis has been found in developmental differences in priming, where abstract priming remains relatively constant from 3 years of age until adulthood, but the lexical boost grows over development (Rowland, Chang, Ambridge, Pine, \& Lieven, 2012). Further evidence is provided by Hartsuiker, Bernolet, Schoonbaert, Speybroeck, and Vanderelst (2008), who found that the lexical boost decayed more quickly than abstract structural priming when prime and target were separated by intervening sentences. If the lexical boost decays quickly, then it only represents a temporary link between the lexicon and syntax, and it does not provide evidence for long-term lexicalized syntactic representations.

The lemma-based and learning account of priming can be contrasted by examining priming in German, where structural choices depend inter alia on tense and aspect. German has two canonical positions for verbs, verb-second (V2) and verb-final (VF). The verb-second position can be seen in the German equivalent of the present tense sentence "the mistress sends the gentleman the bill," with the finite verb sendet in the second position after the subject die Geliebte $(1,2)$. The verb-final structure puts the non-finite verb in sentence-final position and an auxiliary is placed in second position $(3,4)$. When the auxiliary is a form of sein ("to be") or haben ("to have"), the action is called perfective, meaning that it has been completed. When the auxiliary is a form of werden ("to become"), the utterance is in the future tense. When perfective, the final verb is the participle (gesandt), and in future tense it is the infinitive form (senden). Verb-second structures also allow a past-tense description called the simple past (e.g., sandte means "sent"), which in most cases is interchangeable with the perfect form.

1. V2 DO: Die Geliebte sendet dem Kavalier die Rechnung.

2. V2 PD: Die Geliebte sendet die Rechnung an den Kavalier.

3. VF DO: Die Geliebte hat dem Kavalier die Rechnung gesandt.

4. VF PD: Die Geliebte hat die Rechnung an den Kavalier gesandt.

The German alternation between DO and PD is similar to the English dative alternation in terms of structure, but there are differences due to case-marking. In a canonical DO structure $(1,3)$, the first object is marked for dative (dem Kavalier, "gentleman") and the second object is marked for accusative (die Rechnung, "bill"). In a canonical PD structure $(2,4)$, the first object is marked for accusative (die Rechnung) and the prepositional object takes the preposition an ("to") which assigns accusative case (den Kavalier). In language use, the German DO variant is more frequent than its PD counterpart (Melinger \& Dobel, 2005).

Since the lemma-based network models represent lexical and structural choices in production using activated nodes, it is necessary in German to add nodes to represent the choice of verb position (nodes V2 and VF in top of Fig. 1). Since this choice depends on tense and aspect, there need to be links between the tense/aspect nodes and these verb position nodes. As the verb position nodes are not linked to the structure nodes, this German lemma model predicts that priming will be the same across both verb positions. Alternatively, the verb position nodes might be linked to the structure nodes and this German position-structure lemma model would predict greater priming when the verb 


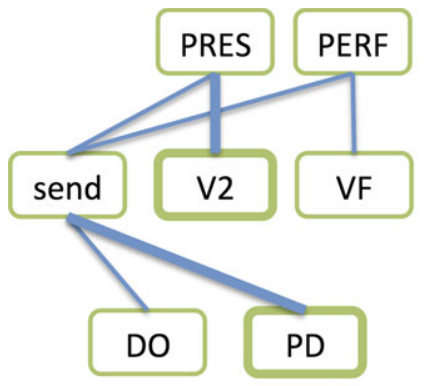

German lemma model:

Verb position nodes (V2/VF)

activated by tense/aspect nodes

Abstract priming due to residual activation in PD node (thick outline)

Lexical boost due to activation in link from lemma to PD node (thick link)

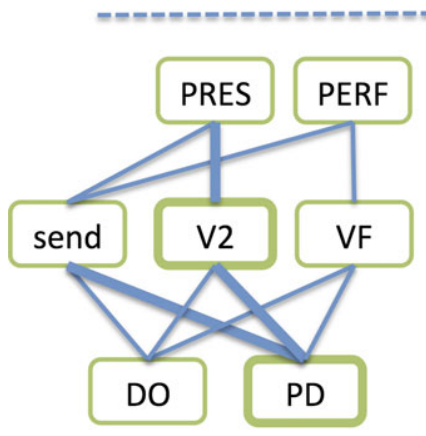

German position-structure lemma model:

Residual activation between verb position nodes and structure nodes predicts verb position boost

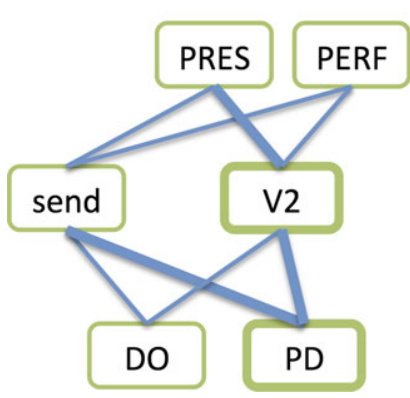

English position-structure lemma model:

Residual activation between tense/ aspect nodes and structure nodes predicts that priming will be sensitive to tense/aspect

Fig. 1. Lemma-based models of English and German production. Residual activation in nodes and links is signaled by thick lines.

position matches between prime and target (verb position boost, middle Fig. 1). But importantly, if the assumptions of this model are characteristic of the architecture of sentence production (rather than just German production), then a verb position node must also mediate between tense/aspect and structural choices in English (bottom Fig. 1). Hence, overlap in tense/aspect modulates priming in this English position-structure lemma model and that is at odds with the results in Pickering and Branigan (1998).

The learning approach argues that the architecture of production does not need to be identical across different languages. It is possible that verb position-structure links develop for one language, but not for another, depending on the structural options in each language. For example, Chang (2009) showed that the Dual-path model learned distinct 
language-specific syntactic biases in English and Japanese sentence production (Hawkins, 2004; Yamashita \& Chang, 2001). Even within a language like English (Chang et al., 2006), the Dual-path model learned both thematic-role-independent structures that supported locative-passive priming (Bock \& Loebell, 1990) and thematic-role-dependent structures that supported priming with the spray-load locative alternation (Chang, Bock, \& Goldberg, 2003). The model learned lemma-like representations where variation in tense/aspect did not modulate priming in English (Chang et al., 2006), because structural decisions in the input did not depend on tense/aspect. In German they do, and hence the learning-based account predicts that priming will differ in English and German.

\section{Verb position and overlap in structural priming in German speakers}

To compare the lemma-based and learning-based accounts, we conducted a structural priming study in German. We crossed sentence structure (DO/PD), verb overlap (same/ different verbs), and verb position (V2/VF). Targets were presented as a vertical list of content words (e.g., senden Bürgermeister Petition Minister "send mayor petition minister") from which speakers typically generate sentences in present tense with a V2 structure (Pappert \& Pechmann, 2013). The German lemma model (Fig. 1, top), like the English lemma model (Pickering \& Branigan, 1998), predicts a lexical boost when verbs overlap, but tense/aspect should not modulate abstract priming or the boost, because there are no links between verb position nodes and structural nodes. The German positionstructure lemma model (Fig. 1, middle) predicts that tense/aspect should influence priming through links between verb position and structure nodes. When this model is adapted for English (Fig. 1, bottom), it becomes inconsistent with English priming results. Thus, a learning-based account would be needed to explain why the architecture of sentence production varies across these two languages.

\subsection{Method}

\subsubsection{Participants}

Sixty-four native speakers of German (38 females) were paid for their participation in the study. They were between 18 and 38 years old (mean: 27).

\subsubsection{Materials}

Forty-eight German prime sentences were constructed around 12 dative alternation verbs (used four times each). Particle verbs were not used, because the particle always strands in verb-final position. The primes were paired with 48 targets consisting of one of the 12 dative alternation verbs followed by three nouns. Primes occurred as PD or DO structure with either a V2 main verb (present or simple past) or a VF verb with a finite auxiliary in second position (perfect or future; tenses were balanced across items). Verb overlap was manipulated by placing the same or different verbs in prime and target. 
Prime-target pairs are listed in the Appendix. Prime sentences were spoken by a native German speaker and digitally recorded.

Eight experimental lists were created that counterbalanced the prime conditions across items. Ninety-six filler prime-and-target pairs were intermixed with the critical items. The order of the total of 144 trials was pseudo-randomized.

\subsubsection{Procedure}

A primed sentence generation experiment (Pappert \& Pechmann, 2013) was run with E-Prime 2.0 software (Psychology Software Tools, Pittsburgh, PA, USA; Schneider, Eschman, \& Zuccolotto, 2002) in a sound attenuated chamber. The experiment began with a practice block. A priming trial started with a fixation star in the center of the monitor and the prime sentence was presented via loudspeakers. The participant repeated the prime aloud and the experimenter confirmed the repetition by a button press. After that, target words were presented on the screen for 1,300 ms. They were aligned vertically in a top-to-bottom order (verb, agent, theme, recipient), an order that biases toward a PD structure and helps to overcome the strong German DO preference. Participants articulated a complete sentence aloud and the experimenter coded the answer by a button press. A session lasted about $35 \mathrm{~min}$ and was recorded for off-line coding.

\subsubsection{Coding}

The responses were coded in terms of structure (DO, PD), verb type (present, simple past, perfect, future), and whether the structure was canonical or marked. Marked sentences were scrambled versions of the canonical DO/PD form such as the marked DO structures Der Mann sendet den Brief dem Freund which is akin to "The man sends the letter the friend." Out of a total of 118 marked structures, $84 \%$ were DO. We required that the targets were either unmarked PD or DO structures with the verb in second position, and this led to the exclusion of 38\% responses after PD primes and 37\% after DO primes. These excluded responses were made up of marked present tense $(7 \%)$, marked simple past (2\%), future tense (4\%), perfect (4\%), and invalid responses (83\%). Responses were coded as invalid if participants left out or substituted target words, produced non-DO/PD structures, or failed to produce a grammatical response. Seven participants were recoded by a second coder that was blind to the hypotheses and high agreement between coders was achieved (Cohen's kappa $=0.92)$.

\subsection{Results}

Binomial mixed models were applied to the production of DO structures with prime structure (PD, DO), verb overlap (same, different), and verb position (second, final) fully crossed (Fig. 2 shows average percent DO responses across these conditions). Factors were effect coded and subjects and items were entered as random variables. The maximal model that converged contained random slopes for structure and verb position for subjects, and random slopes for structure, verb overlap, and verb position for items (Barr, Levy, Scheepers, \& Tily, 2013). Likelihood-ratio tests were used to compute $p$-values. 


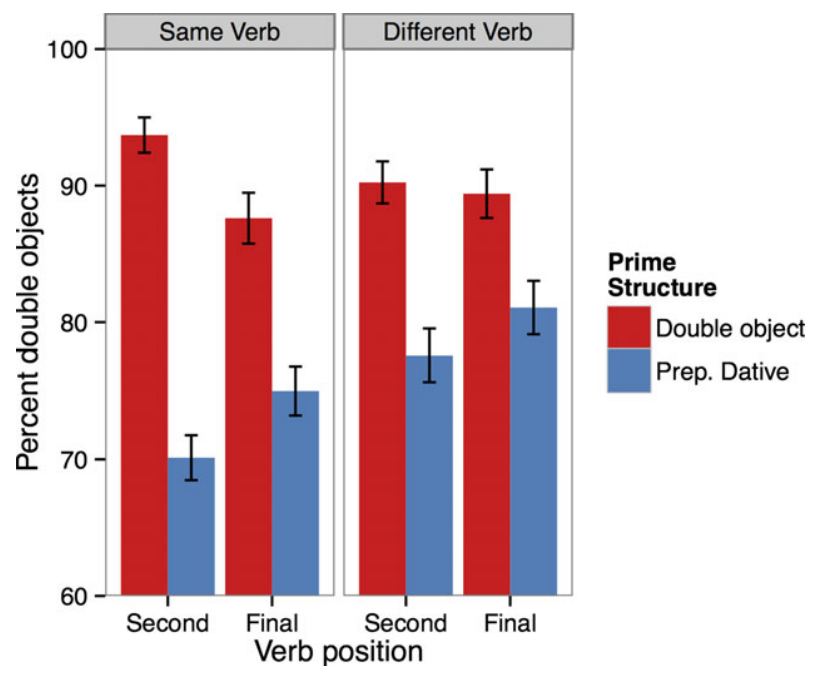

Fig. 2. German human structural priming results for verb overlap and verb position (standard error bars generated with remef, sample size $=64$, Hohenstein \& Kliegl, 2013).

There was a main effect of prime structure, where DO production was higher after DO primes than after PD primes $\left(b=1.60, S E=0.20, \chi^{2}(1)=33.5, p<.001\right)$. There was an interaction of prime structure and verb position $\left(b=1.05, S E=0.33, \chi^{2}(1)=8.7\right.$, $p<.004)$, which means that overlap in verb position created a verb position boost on structural priming. There was a main effect of verb overlap $(b=-0.33, S E=0.18$, $\left.\chi^{2}(1)=6.5, p<.02\right)$ and an interaction of structure and verb overlap $(b=0.66$, $\left.S E=0.32, \chi^{2}(1)=4.1, p<.05\right)$, which shows that the effect of prime structure was larger when the verb was the same between prime and target (lexical boost). To ensure that priming occurred at each verb position, separate models were created crossing structure and verb overlap. In V2 position, there was abstract priming (priming $=18.2 \%, b=2.9$, $\left.S E=0.39, \chi^{2}(1)=28.8, p<.001\right)$ and a lexical boost $\left(b=1.2, S E=0.52, \chi^{2}(1)=5.1\right.$, $p<.03$ ). In VF position, there was only abstract priming (priming $=10.3 \%, b=1.1$, $\left.S E=0.24, \chi^{2}(1)=9.76, p<.002\right)$, but no lexical boost $(p=.7)$.

\section{A German Dual-path model of priming}

The results in the experiment broadly support the German position-structure lemma model. Since the architecture of that model is inconsistent with the English model in Pickering and Branigan (1998), it is worthwhile to explore whether a model of language acquisition can explain the development of the language-specific production systems in these two languages. The Dual-path model has already shown that it can explain structural priming results in English where priming was insensitive to tense/aspect (Chang et al., 2006). In this section, we examine whether the same model can learn to produce 
German sentences and whether the German model shows sensitivity to overlap in tense/ aspect in the verb position boost.

A German version of the Dual-path model was created by training the model on a simple German language with intransitive, transitive, and dative structures that could occur in both PD and DO forms. Sentences in the language were paired with messages that encoded their meaning (5 is the message for sentences 6, 7). For simplicity, English words were used to label concepts and content words in the model (the labels play no role in the model's behavior).

5. Message: $A=$ SEND $X=B R O T H E R ~ Y=A P P L E ~ Z=U N C L E ~ E=P R E S E N T, X X, Y Y, Z Z$

6. Sentence: der brother send den apple an den uncle

7. Sentence: der brother send dem uncle den apple

8. Sentence: der brother hat den apple an den uncle send

9. Sentence: der brother hat dem uncle den apple send

Messages (5) were composed of four role variables (A for action, X for agent, $\mathrm{Y}$ for patient/theme, $\mathrm{Z}$ for recipient) and event-semantics that encoded the number of arguments. For example, a dative structure had event-semantics with features XX, YY, and $\mathrm{ZZ}$ activated to encode the fact that there were arguments for the $\mathrm{X}, \mathrm{Y}$, and $\mathrm{Z}$ roles. The event-semantics also encoded the tense of the verb (PRESENT, PERFECT) and the verb position varied accordingly. The present tense PD form (6) had the same message as the DO form (7), and therefore the model had to choose the structure itself. The perfect tense forms $(8,9)$ had the same message $(5)$ except in the event-semantics the PRESENT feature was replaced with the PERFECT feature. In the model's input language, there were eight verbs for each structure. There were 14 animate nouns and 14 inanimate nouns. Nouns were roughly distributed into the three genders (masculine, feminine, neuter). Articles were all definite and agreed with nouns in gender and case (nominative, accusative, dative). There were four adjectives that occurred on noun phrases $20 \%$ of the time. Adding optional adjectives creates positional variation in the verb and nouns, which forces the model to learn position-independent cues for syntax. Verbs had the same form in both verb-second and verb-final position to make the model more comparable to the lemma account. Datives were biased toward the DO structure (75\%) to reflect the bias in German speakers (German production studies report similar biases with and without priming: $80 \%$ and 70\% DO, respectively, Pappert \& Pechmann, 2013, 2014).

The message-sentence pairs were used to train the Dual-path model (Chang, 2002). The architecture of the Dual-path model has sequencing and meaning pathways (Fig. 3). The sequencing pathway was a simple recurrent network, which learns syntactic representations by predicting the next word in sentences, one word at a time. The difference between the model's prediction and the actual next word, which is called error, is used by the learning algorithm (back-propagation, Rumelhart, Hinton, \& Williams, 1986) to change the weights in the network to enhance future predictions (error-based learning, Dell \& Chang, 2014). This network maps from the previous word in the PrevWords layer to the Hidden layer and then to the Words layer, through compression layers (CompCompress, Compress) that force the model to compress lexical information into syntactic cate- 
gories. There is also a Context layer, which holds a copy of the previous Hidden layer activation and this allowed the network to learn whole sentence structures. These syntactic sequences in the Hidden layer interacted with the message representations in the meaning pathway. The Role-Concept links (thick gray lines in Fig. 3) were used to encode the message. The sequencing system learned to activate the roles, which caused the appropriate concept to become activated and the model learned how that concept maps to words in the language (Word layer). The CompConcepts and CompRoles helped the model to determine the role of the previous word, which allowed it to alternate between structures based on previous word choices. To enhance the model's memory for the roles that have been produced, there was also a CompRoles2 layer which held a running average of the CompRoles activations.

Thirty training sets of 20,000 message-sentence pairs were created to train 30 model subjects for 20,000 patterns. The message was excluded from $50 \%$ of the training pairs to increase the syntactic nature of the learned representations. All models were tested every 2,000 epochs on the same test set made up of 50 prime-target pairs for each combination of structure, position, and overlap. The target was always present tense (verb-second), the prime could be either present or perfect tense (verb-final) and there was no noun overlap

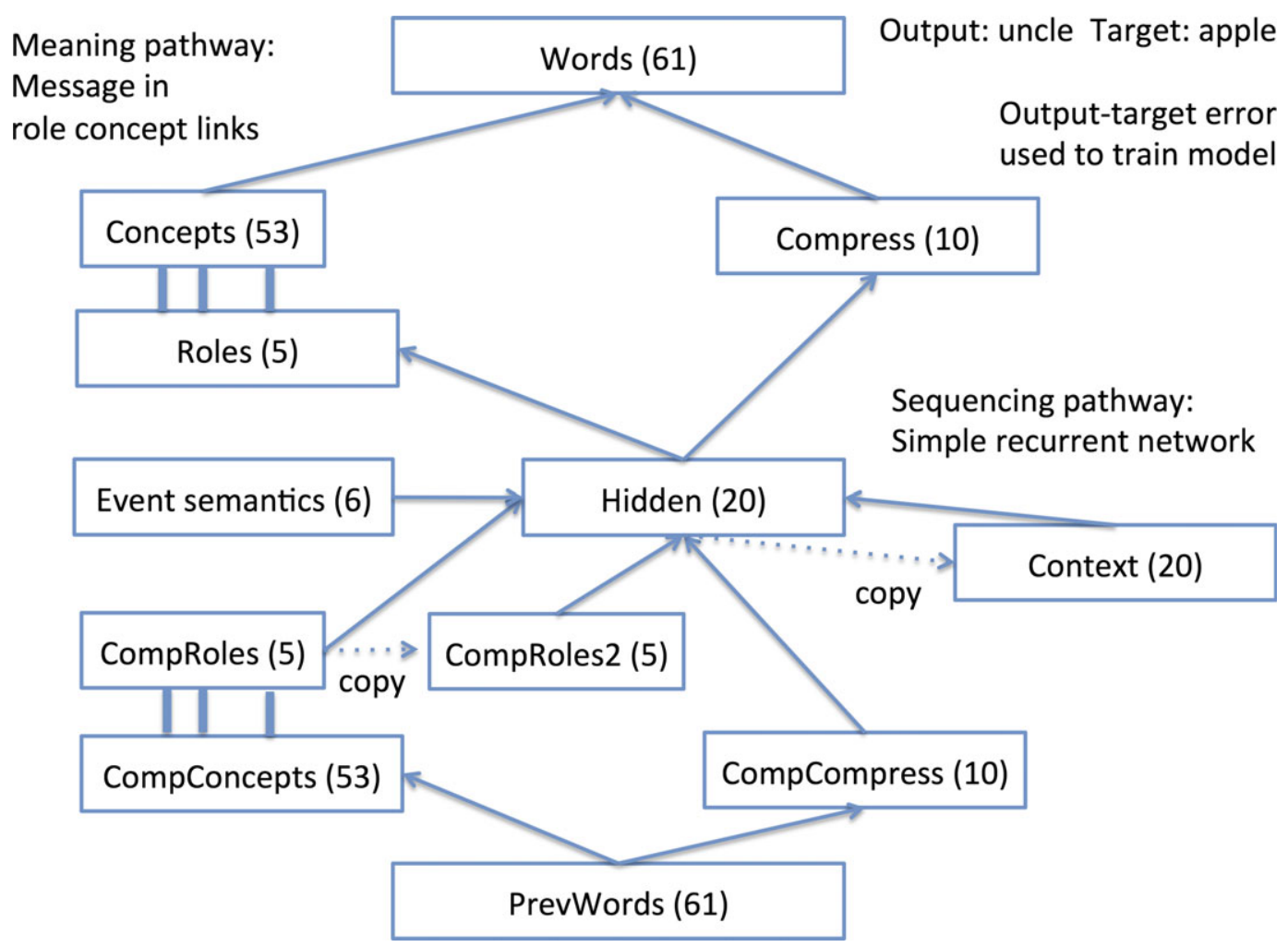

Fig. 3. Dual-path model architecture. Layers are shown with size in parentheses. 
between prime and target. The prime-target pair could have the same or different verbs. As in Chang et al. (2006), primes were presented with learning left on and without messages, because speakers do not know the message of a prime before they hear the sentence. Since the model's input language was smaller and more uniform than real German input, prediction error was smaller in the model and the magnitude of priming effects may not match those in human studies. Therefore, while the learning rate for training was 0.2 , the learning rate at test was three times larger (0.6) to make the priming magnitude larger. Targets had a message that was equally compatible with either a DO or PD structure. To measure adult priming, we computed the average proportion of DO structures produced including only correctly produced DO and PD structures for the last five testing points for each model subject (Fig. 4 shows mean percent DO production across conditions).

A mixed effects model was applied to the logit-transformed DO proportion for each model subject with prime structure, verb position, and verb overlap crossed. Model subject was a random intercept with structure, position, and overlap as random main-effect slopes (Barr et al., 2013). Likelihood-ratio tests were used to compute $p$-values. There was a main effect of structure where DO production increased after DO primes relative to PD primes $\left(b=0.40, S E=0.04, \chi^{2}(1)=23.8, p<.001\right)$ and this structural priming effect was boosted when both prime and target were verb-second $(b=0.29, S E=0.06$, $\left.\chi^{2}(1)=20.9, p<.001\right)$. There was a main effect of verb position $(b=-0.18, S E=0.03$, $\left.\chi^{2}(1)=22, p<.001\right)$. As in the previous English model (Chang et al., 2006), there was no lexical boost $(p=.48)$. Separate verb-position-specific models were created crossing structure and overlap. In both positions, there was abstract priming (V2 priming $=6.4 \%$,

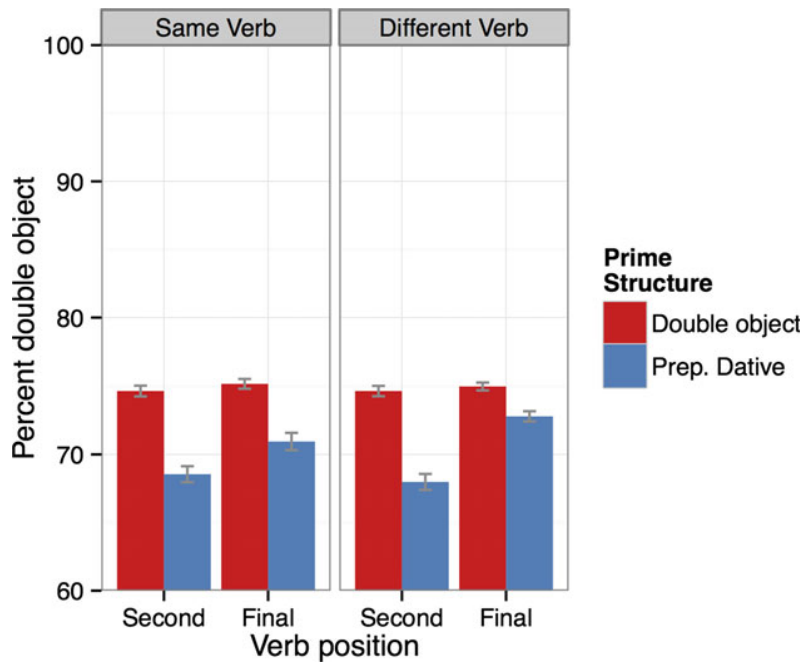

Fig. 4. German model structural priming results for verb overlap and verb position (standard error bars generated with remef, sample size $=30$, Hohenstein \& Kliegl, 2013). 
$b=0.54, S E=0.05, \chi^{2}(1)=46.3, p<.001 ; \mathrm{VF}$ priming $=3.2 \%, b=0.25, S E=0.06$, $\left.\chi^{2}(1)=14.8, p<.001\right)$, but no interaction with overlap (V2, $p=.69$; VF, $p=.16$ ).

These results show that the same learning mechanism used to explain English language acquisition and priming can explain the acquisition of a German-like language with its multiple verb positions and gender/case marked articles. Furthermore, when the same learning mechanism was left on in the adult model, it exhibited abstract structural priming, even across verb positions, as is shown by the main effect of structure. Since there was no message during prime processing, this effect was not due to overlap in the roles or event-semantic units. Rather, the model learned small adjustments to syntactic subsequences in the sequencing system while processing the prime. Since DO versus PD structures had similar subsequences across different verb positions, the model learned verb-position-independent representations for these structures and this explains the main effect of structure. The sequencing system also learned different subsequences for V2 and VF verbs combined with PD/DO structures. When the same V2-structure subsequence was used for both prime and target, then changes to this subsequence on the prime transferred to the target. But when there were changes to the VF-structure subsequence on the prime, it did not transfer to the V2 target. This created the verb position boost effect. These verb effects in the model involve an abstract category of verb, not individual lexical items. Thus, the model did not exhibit the lexical boost and this is consistent with the view that the lexical boost is due to a different mechanism than abstract priming (Chang, Janciauskas, \& Fitz, 2012). In sum, this work demonstrates that a learning-based account predicts an effect of verb position on German priming, and this differs from the predictions of lemma-based accounts that use the same architecture for English and German.

\section{Discussion}

The German priming results provide evidence that verb position can boost the magnitude of structural priming. Within lemma-based models like the German position-structure lemma model (Fig. 1), this boost would be explained by residual activation between verb position nodes and structural nodes. But since verb position depends on tense/aspect in German, there must also be links from tense/aspect nodes and hence there is a chain where tense/aspect overlap can influence structural priming. This can be seen clearly in the English position-structure model where overlap in tense/aspect would leave residual activation in the link between the tense/aspect nodes and the verb node as well as between the verb node and the structure nodes. When the target is produced and the same tense/aspect node is activated, then spreading activation should enhance the same structural choice that was seen on the prime. But this enhancement was not found in English (Pickering \& Branigan, 1998). Thus, the English and German data seem to support different architectures within a lemma-based account.

Lemma-based models are often used as post-hoc redescriptions of experimental data in network format. In this descriptive approach, the model can be changed to fit any data 
set. For the lemma-based account to be more than a mere redescription of the data, it must make some explicit universal claims about the architecture of sentence production that can be tested. For example, the Pickering and Branigan (1998) lemma model does not predict the verb position boost and hence this model is falsified by our German data. The position-structure lemma model predicts variation in priming with tense/aspect in English, and this in turn is falsified by Pickering and Branigan's data. Thus, when we treat these lemma models as theories that make concrete predictions, we find that neither theory provides full coverage of both languages.

Learning-based approaches explain these cross-linguistic differences in a straightforward way. Language processing differs across languages, because the internal networks that are needed are specific to the particular sequences that are found in each language. In languages like German, where verb position depends on tense/aspect, a learner should link tense/aspect information to structural choices. In English where syntactic choices do not vary with tense/aspect, abstract lemma-like representations are the most optimal representations to be learned. Although this account may seem simple, it is non-trivial to build a language acquisition system that can learn abstract syntactic representations that match those in human sentence production studies. To our knowledge, the Dual-path model is the only model that can use the same learning mechanism to explain how syntactic structures are acquired and how they are changed in structural priming (Chang et al., 2006). Even though English versions of the Dual-path model were insensitive to overlap in tense/aspect, we have shown here that the model can learn the dependency in German syntax between tense/aspect and verb position. Furthermore, the same learning mechanism in the adult German model creates a verb position boost in priming.

At stake here is whether the sentence production system has a universal architecture with lemmas that separate tense/aspect from structural nodes. Our results challenge this assumption, because they suggest a link between tense/aspect, verb position nodes, and structural nodes, which violates the separation posited by the account of Pickering and Branigan (1998). In contrast, the learning-based approach argues that there are universal constraints on language learning and these constraints determine the architecture of the adult production system. This approach allows us to explain the language-specific character of production during language acquisition (e.g., Abbot-Smith \& Behrens, 2006; Behrens, 2006) as well as the differences in priming in adult speakers as in our study.

\section{Acknowledgments}

The experiment reported in this article was supported by a grant from the Deutsche Forschungsgemeinschaft (PA 1519/2) to the third author. Hartmut Fitz was funded by the Netherlands Organization for Scientific Research (NWO) under grant no. 275-89-008. Model code is available at http://sites.google.com/site/sentenceproductionmodel/Home/ german-model. 


\section{References}

Abbot-Smith, K., \& Behrens, H. (2006). How known constructions influence the acquisition of new constructions: The German periphrastic passive and future constructions. Cognitive Science, 30(6), 9951026.

Barr, D. J., Levy, R., Scheepers, C., \& Tily, H. J. (2013). Random effects structure for confirmatory hypothesis testing: Keep it maximal. Journal of Memory and Language, 68(3), 255-278. doi:10.1016/j. jml.2012.11.001.

Behrens, H. (2006). The input-output relationship in first language acquisition. Language and Cognitive Processes, 21(1-3), 2-24. doi:10.1080/01690960400001721.

Bock, K. (1986). Syntactic persistence in language production. Cognitive Psychology, 18(3), 355-387.

Bock, K., Dell, G. S., Chang, F., \& Onishi, K. H. (2007). Persistent structural priming from language comprehension to language production. Cognition, 104(3), 437-458.

Bock, K., \& Griffin, Z. M. (2000). The persistence of structural priming: Transient activation or implicit learning? Journal of Experimental Psychology: General, 129(2), 177-192.

Bock, K., \& Loebell, H. (1990). Framing sentences. Cognition, 35(1), 1-39.

Bresnan, J. (2001). Lexical-functional syntax. Malden, MA: Blackwell.

Chang, F. (2002). Symbolically speaking: A connectionist model of sentence production. Cognitive Science, 26(5), 609-651.

Chang, F. (2009). Learning to order words: A connectionist model of heavy NP shift and accessibility effects in Japanese and English. Journal of Memory and Language, 61(3), 374-397.

Chang, F., Bock, K., \& Goldberg, A. E. (2003). Can thematic roles leave traces of their places? Cognition, 90(1), 29-49.

Chang, F., Dell, G. S., \& Bock, K. (2006). Becoming syntactic. Psychological Review, 113(2), 234-272.

Chang, F., Janciauskas, M., \& Fitz, H. (2012). Language adaptation and learning: Getting explicit about implicit learning. Language and Linguistics Compass, 6(5), 259-278.

Dell, G. S., \& Chang, F. (2014). The P-chain: Relating sentence production and its disorders to comprehension and acquisition. Philosophical Transactions of the Royal Society B: Biological Sciences, 369(1634), 20120394, 1471-2970. doi:10.1098/rstb.2012.0394.

Hartsuiker, R. J., Bernolet, S., Schoonbaert, S., Speybroeck, S., \& Vanderelst, D. (2008). Syntactic priming persists while the lexical boost decays: Evidence from written and spoken dialogue. Journal of Memory and Language, 58(2), 214-238.

Hawkins, J. A. (2004). Efficiency and complexity in grammars. New York: Oxford University Press.

Hohenstein, S., \& Kliegl, R. (2013). remef (REMove EFfects) (version v0.6.10). Available at: http://read. psych.uni-potsdam.de/joomla/attachments/article/12/remef.v0.6.10.R. Accessed Jan 20, 2014.

Levelt, W. J. M., Roelofs, A., \& Meyer, A. S. (1999). A theory of lexical access in speech production. Behavioral and Brain Sciences, 22(1), 1-38.

Melinger, A., \& Dobel, C. (2005). Lexically-driven syntactic priming. Cognition, 98(1), B11-B20. doi:10. 1016/j.cognition.2005.02.001.

Pappert, S., \& Pechmann, T. (2013). Bidirectional structural priming across alternations: Evidence from the generation of dative and benefactive alternation structures in German. Language and Cognitive Processes, 28(9), 1303-1322. doi:10.1080/01690965.2012.672752.

Pappert, S., \& Pechmann, T. (2014). Unpublished raw data. Leipzig, Germany: University of Leipzig.

Pickering, M. J., \& Branigan, H. P. (1998). The representation of verbs: Evidence from syntactic priming in language production. Journal of Memory and Language, 39(4), 633-651.

Pollard, C., \& Sag, I. A. (1994). Head-driven phrase structure grammar. Chicago, IL: University of Chicago Press.

Reitter, D., Keller, F., \& Moore, J. D. (2011). A computational cognitive model of syntactic priming. Cognitive Science, 35(4), 587-637. 
Rowland, C. F., Chang, F., Ambridge, B., Pine, J. M., \& Lieven, E. V. M. (2012). The development of abstract syntax: Evidence from structural priming and the lexical boost. Cognition, 125(1), 49-63. doi:10. 1016/j.cognition.2012.06.008.

Rumelhart, D. E., Hinton, G. E., \& Williams, R. J. (1986). Learning representations by back-propagating errors. Nature, 323(6088), 533-536.

Schneider, W., Eschman, A., \& Zuccolotto, A. (2002). E-Prime: User's guide. Pittsburgh, PA: Psychology Software Incorporated.

Yamashita, H., \& Chang, F. (2001). "Long before short" preference in the production of a head-final language. Cognition, 81(2), B45-B55.

\section{Appendix: Experimental items: Prime-target pairs}

Prime sentences varied in structure (DO vs. PD), verb position (V2 vs. VF), and verb overlap (same vs. different verb in prime and target). Below, prime sentences are listed in the V2 (present or simple past) DO condition with the different/same verb only. Note that the English translation equivalents of the German dative alternation verbs do not necessarily alternate.

1. Die Großmutter schickt/überreicht ihrem Enkel ihr Testament.

"The grandmother sends/hands her grandson her will."

überreichen Pförtner Schlüssel Mitarbeiter

"hand doorman key co-worker"

2. Der Adjutant sendet/überreicht dem Offizier den Bericht.

"The aide-de-camp sends/hands the officer the report."

überreichen Fan Rose Sänger

"hand fan rose singer"

3. Der Auszubildende lieferte/überreichte dem Meister die Ersatzteile.

"The apprentice delivered/handed the master the spare parts."

überreichen Kobold Schatz Prinz

"hand leprechaun treasure prince"

4. Der Zirkusdirektor vererbte/überreichte dem Zoo die Käfige.

"The ringmaster bequeathed/handed the zoo the cages."

überreichen Zimmermädchen Ventilator Gast

"hand maid ventilator guest"

5. Martin übergibt/schickt der Mutter den Brief.

"Martin transfers/sends the mother the letter."

schicken Notarin Mahnung Filialleiter

"send notary reminder manager"

6. Die Agentur übermittelt/schickt der Behörde die Daten.

"The agency transfers/sends the authority the data."

schicken Versandhaus Katalog Kundin

"send mail_order_company catalogue customer" 
7. Der Onkel vermachte/schickte der Nichte die Lieblingspuppe.

"The uncle bequeathed/sent the niece the favourite doll."

schicken Rechtsanwalt Vertrag Klient

"send attorney contract client"

8. Die Spedition lieferte/schickte dem Raumausstatter die Möbel.

"The moving company delivered/sent the interior decorator the furniture."

schicken Tante Paket Neffe

"send aunt package nephew"

9. Die Geliebte übergibt/sendet dem Kavalier die Rechnung.

"The mistress transfers/sends the gentleman the bill."

senden Bürgermeister Petition Minister

"send mayor petition minister"

10. Die Gemeinde überreicht/sendet dem Verein die Urkunde.

"The community hands/sends the club the certificate."

senden Sekretärin Post Chef

"send secretary mail boss"

11. Die Gewerkschaft übermittelte/sendete dem Vorstand die Beschwerde.

"The union transferred/sent the board of directors the complaint."

senden Bürohilfe Abrechnung Verwalter

"send assistant bill administrator"

12. Der Krieger überbrachte/sendete der Prinzessin die Botschaft.

"The warrior delivered/sent the princess the message."

senden Hersteller Ware Vertreter

"send manufacturer merchandise agent"

13. Der Waldarbeiter übergibt/liefert dem Förster den Baumstamm.

"The lumberjack transfers/delivers the forest warden the trunk."

liefern Bote Blumenstrauß Ehegattin

"deliver messenger bouquet spouse"

14. Der Bäcker spendet/liefert der Suppenküche die Brötchen.

"The baker donates/delivers the soup kitchen the rolls."

liefern Agent Geheimdokumente Auftraggeber

"deliver agent secret_documents contractor"

15. Der Schiffbauer verkaufte/lieferte dem Kapitän das Boot.

"The shipbuilder sold/delivered the captain the boat."

liefern Detektiv Fotos Polizei

"deliver detective photos police"

16. Der Designer überreichte/lieferte dem Geschäft die Sommerkollektion.

"The designer handed/delivered the shop the summer collection."

liefern Apotheker Medikamente Rentner

"deliver pharmacist medicine pensioner"

17. Der Mechaniker vermietet/verkauft dem Kunden den Wagen.

"The mechanic rents/sells the customer the car."

verkaufen Künstler Postkarten Touristen

"sell artist postcards tourists" 
18. Der Manager schickt/verkauft dem Rockstar das Kokain.

"The manager sends/sells the rock star the cocaine."

verkaufen Autor Manuskript Verlag

"sell author manuscript publisher"

19. Der Berater übermittelte/verkaufte dem Ehepaar die Wertpapiere.

"The consultant transferred/sold the married couple the security papers."

verkaufen Züchter Futter Bauer

"sell breeder foodstuff farmer"

20. Der Dieb übergab/verkaufte dem Schrotthändler das Fahrrad.

"The thief transferred/sold the junk dealer the bicycle."

verkaufen Komponist Rechte Plattenlabel

"sell composer rights record_company"

21. Der Vater vererbt/übergibt dem Jungen die Briefmarkensammlung.

"The father bequeaths/transfers the boy the stamp collection."

übergeben Inhaber Firmenleitung Geschäftsführer

"transfer owner charge_of_the_company director"

22. Der Entwicklungshelfer spendet/übergibt dem Dorf den Brunnen.

"The development worker donates/transfers the village the well."

übergeben Klassenlehrer Zeugnis Schüler

"transfer teacher certificate pupil"

23. Die Reporterin sendete/übergab dem Interviewpartner die Fragen.

"The reporter sent/transferred the interviewee the questions."

übergeben Kunsthändler Fälschung Kripo

"transfer art_dealer counterfeit criminal_investigation_department"

24. Das Rechenzentrum schickte/übergab dem Studenten das Passwort.

"The computing centre sent/transferred the student the password."

übergeben Arzt Spritze Patient

"transfer doctor syringe patient"

25. Das Radio sendet/übermittelt dem Publikum die Nachrichten.

"The radio sends/transfers the public the news."

übermitteln Single Anzeigentext Partnerbörse

"transfer single advertisement_text dating_site"

26. Das Bürgeramt verkauft/übermittelt der Werbeagentur die Personendaten.

"The municipal office sells/transfers the advertising company the personal data."

übermitteln Angestellter Anfrage Kollege

"transfer employee inquiry colleague"

27. Die Rezeptionistin überreichte/übermittelte dem Handlungsreisenden den Zimmerschlüssel.

"The concierge handed/transferred the commercial traveller the room key."

übermitteln Beamter Rufnummer Verwaltung

"transfer civil_servant telephone_number administration"

28. Die Presseagentur überbrachte/übermittelte der Redaktion die Informationen.

"The press agency delivered/transferred the editorial office the information."

übermitteln Teamleiter Vollmacht Hilfskraft

"transfer team_leader authorisation assistant" 
29. Der Großvater vermietet/vermacht der Schwiegertochter den Garten.

"The grandfather rents/bequeaths the daughter-in-law the garden."

vermachen Mann Juwelen Gärtnerin

"bequeath man jewels gardener"

30. Susann verkauft/vermacht ihrer Schwester ihr Ballkleid.

"Susann sells/bequeaths her sister her ball gown."

vermachen Millionär Grundstück Haushaltshilfe

"bequeath millionaire property household_help"

31. Die Erbin spendete/vermachte dem Kinderheim die Büchersammlung.

"The heiress donated/bequeathed the children's home the book collection." vermachen Musiker Plattensammlung Exfrau

"bequeath musician record_collection ex-wife"

32. Die Witwe überbrachte/vermachte dem Mädchen das Familienalbum.

"The widow delivered/bequeathed the girl the family album."

vermachen Großtante Tafelsilber Patenkind

"bequeath grand_aunt silver godchild"

33. Der Regieassistent liefert/überbringt dem Produzenten das Drehbuch.

"The assistant director delivers/delivers the producer the script."

überbringen Druckerei Plakate Veranstalter

"deliver print_shop posters organizer"

34. Der Limousinenservice vermietet/überbringt den Abiturienten das Auto.

"The limousine service rents/delivers the graduates the car."

überbringen Zeuge Tatwaffe Ermittler

"deliver witness murder_weapon investigator"

35. Das Büro übermittelte/überbrachte der Kanzlei das Schreiben.

"The office transferred/delivered the law firm the document."

überbringen Lotterie Jackpot Gewinner

"deliver lottery jackpot winner"

36. Der König vermachte/überbrachte dem Thronfolger die Krone.

"The king bequeathed/delivered the heir to the throne the crown."

überbringen Kurierdienst Bestellung Hausfrau

"deliver courier_service order housewife"

37. Das Orchester vermacht/spendet der Musikschule die Instrumente.

"The orchestra bequeaths/donates the music school the instruments."

spenden Bürger Millionen Hilfsorganisation

"donate citizens millions aid_organisation"

38. Der Wissenschaftler vererbt/spendet dem Institut die Messgeräte.

"The scientist bequeaths/donates the institute the measurement devices."

spenden Autohaus Einnahmen Grundschule

"donate car_dealership profits elementary_school"

39. Der Supermarkt lieferte/spendete dem Obdachlosenheim die Lebensmittel.

"The supermarket delivered/donated the homeless shelter the foods."

spenden Maler Skizzen Galerie

"donate painter sketches gallery" 
40. Die Diakonie überbrachte/spendete der Kinderklinik das Spielzeug.

"The social welfare work delivered/donated the child clinic the toys." spenden Sammler Statue Museum

"donate collector statue museum"

41. Die Umzugsfirma verkauft/vermietet der Wohngemeinschaft die Kartons.

"The removal company sells/rents the commune the cardboard boxes." vermieten Landwirt Traktor Biohof

"rent farmer tractor organic_farm"

42. Der Lesezirkel sendet/vermietet der Arztpraxis die Zeitschriften.

"The magazine subscription service sends/rents the doctor's office the magazines." vermieten Kostümverleih Anzüge Theater "rent costume_rental dresses theatre"

43. Peter vererbte/vermietete dem Sohn das Haus.

"Peter bequeathed/rented the son the house." vermieten Baumarkt Transporter Heimwerker "rent hardware_store delivery_van handyman"

44. Der Pferdehalter vermachte/vermietete dem Gestüt den Zuchthengst.

"The horse owner bequeathed/rented the farm the stud horse." vermieten Stadt Schrebergarten Familie "rent city garden family"

45. Die Köchin überreicht/vererbt der Tochter die Rezeptesammlung.

"The cook hands/leaves the daughter the recipe collection." vererben Rind Krankheit Nachwuchs "bequeath cattle disease offspring"

46. Der Philosoph spendet/vererbt der Bibliothek die Schriftensammlung. "The philosopher donates/leaves the library the collection of works." vererben Schriftsteller Lebenswerk Nachwelt "bequeath writer life's_work posterity"

47. Die Seniorin vermietete/vererbte dem Nachbarn das Ferienhaus.

"The old lady rented/left the neighbour the holiday house." vererben Frau Edelsteine Cousine "bequeath woman gems cousin"

48. Die Fürstin schickte/vererbte ihrer Amme ihre Diamanten.

"The princess sent/bequeathed her nurse her diamonds." vererben Milliardär Cabrio Chauffeur "bequeath billionaire convertible chauffeur" 